\title{
Comparative Analysis of a Financial Performance on Conventional Banks and Sharia Banks in Indonesia
}

\author{
Wahyu Dwi Yulianto ${ }^{1}$ Arini Wildaniyati ${ }^{2 *}$, Fatchur Rochman ${ }^{3}$ \\ ${ }^{1,2,3}$ Merdeka University of Madiun Jl. Serayu 79, Madiun, Indonesia \\ *Corresponding author. Email: arini@unmer-madiun.ac.id
}

\begin{abstract}
The goal of this analysis was to ascertain the financial output differences of traditional banks and Sharia banks throughout 2014-2018. The collected data in this analysis were secondary data from the financial statements issued by Bank Indonesia. The sampling methodology used in this analysis was for the purposive sampling, so the samples used were 4 samples of traditional banks and 4 samples of Sharia banks taken from conventional banks, which included state-owned banks and Sharia banks with the highest reserves. The analysis technique used to compare the financial results of conventional banks and Sharia banks is the Independent sample t-test method. Performance comparison is measured by financial ratios consisting of CAR, BOPO, ROA, NPL and LDR. The results showed that conventional banks performed better in terms of BOPO, ROA, NPL ratios, while Sharia banks performed better in terms of CAR and LDR ratios.
\end{abstract}

Keywords: Financial performance, Financial ratios

\section{INTRODUCTION}

Banking in Indonesia is a financial entity that holds a crucial part in the country's economy, because banking is one of the financial structures that acts as a financial intermediary, i.e. an entity that has a role to play in putting together fund owners and consumers of funds, and thus banking operations must work on a macro and micro scale. Funds from community mobility are allocated to various kinds of economic sectors and all areas that are needed quickly and precisely. The growth in the mobilization of public funds has not yet helped the traditional banking system and, in order to satisfy the need for banking services in compliance with the principles of Sharia law, Sharia banks were formally opened to the public in 1992. Profit and return sharing are being central in the distinction between traditional and Sharia financial institutions provided by clients to financial institutions and/or provided by financial institutions to clients. [1].

The Indonesian banking industry has experienced ups and downs. Starting in 1983, when various kinds of de-regulation began to be carried out by the government, then the banking business developed rapidly in the 1988-1996 period. In mid-1997, the banking industry finally collapsed as a result of the monetary crisis and the economic crisis that hit the
Indonesian economy. The banking sector in Indonesia has a very significant role to play in the economy. Banks are one of the financial institutions with a significant role to play as a financial intermediary in the economy of a country. The banks referred to in Article 1(2) of Law No. 10 of 1998 concerning amendments to Law No. 7 of 1992 concerning banking is a business entity which collects funds from the public in the form of loans and other means of improving people's standard of living.

The development of the Islamic finance industry was informally initiated before the issuance of the formal legal framework as the basis for banking operations in Indonesia. Several non-bank financing companies were established before 1992, which have implemented the concept of profit sharing in their operations. This shows the public's need for the presence of financial institutions that can provide Sharia financial services. The types of banks in Indonesia are classified into two types of banks: traditional banks and Sharia banks [2]. This is because banking is one of the financial structures that acts as a financial intermediary, an entity that has a role to play in putting together fund owners and customers. Therefore, bank activities must run efficiently on a macro and micro scale. Funds from community mobility are allocated to various economic sectors and 
all areas that are needed, precisely and quickly. In order to maximize the mobilization of public funds not served by the traditional banking system and to satisfy the need for banking facilities in compliance with the principles of Sharia law, Sharia banks were formally opened to the public in 1992.

The key factor that separates typical financial institution banks from Sharia is the acquisition and distribution of income made by clients to financial institutions or by financial institutions to clients [1]. The operating practices of Sharia banks are based on the concept of profit and loss. Sharia banks do not employ interest as a way of gaining profits or differentiating interest on the use of funds and loans because interest is excluded from usury. Bank performance can also show the strengths and weaknesses of a bank. By knowing the strength of a bank, it can be used for bank business development. While the weaknesses can be used as a basis for future improvements. Currently quite a lot of conventional banks have established or opened Sharia branches. Therefore, the researcher would like discover the performance contrast between Sharia banks and traditional banks.

\section{LITERATURE REVIEW}

\subsection{Definition of Bank}

Dendawijaya [3] stated that, "Bank is a business entity whose main task is as a financial intermediary institution, which channels funds from parties that have excess funds to parties who need funds or lack of funds at a specified time."

The key role of Indonesian banking is to raise funds and allocate funds to the public with a view to facilitating the introduction of national development in order to increase the equitable development of economic growth and national peace in order to boost people's living standards [4].

\subsection{Conventional Banks}

Conventional banks are banks which, on a conventional basis and on the basis of their form, carry out their business activities, consisting of conventional commercial banks and rural banks [5].

According to Kasmir [6], commercial banking operations include the following activities: collecting funds (funding), channeling funds (leading) and delivering other banking services (service).

\subsection{Sharia Banks}

Sharia Banks are banks functioning on the basis of Sharia principles and set up by Sharia Commercial Banks and Sharia Rural Banks. Sharia principles are Islamic law principles in the field of fatwas-based banking practices released by institutions with the power of determining fatwas within the Sharia law [5].

According to Muhammad [1] in carrying out its activities, Sharia banks adhere to the following partial principles: Pure Savings Principle (al-Wadi'ah), Profit Sharing Principle (Syirkah), Sale and Purchase Principle (at-Tijarah), Lease Principle (al-Ijarah), Service Principle (al-Ajr walumullah).

\subsection{Differences Between Conventional Banks and Sharia Banks}

According to Antonio [7] mentioned that there are several things which become fundamental differences between conventional banks and Sharia banks, as follow: conventional banks which include: halal and haram investments, using interest devices, profit oriented, relationships with customers in the form of debtor-debtor relationships, there is no such council. Whereas Sharia banks include: only permissible transactions based on the concepts of benefit sharing, purchasing and sale, or lending, profit and falah (falah means finding prosperity in the world and in the hereafter), relationships with consumers in the form of alliances, and receipt and allocation of funds shall comply with the fatwa of the Sharia Supervisory Board..

According to Machmud and Rukmana [8], it is stated that there are several differences between profit sharing and interest rates, among others: interest rates which consist of determination of interest made during the agreement without basing on profit / loss, the percentage of interest based on the amount of money (capital) available, fixed interest payments such as agreements without a consideration is taken whether the project carried out by the second party gains or losses, the amount of interest payments does not increase even though the amount of profit is doubled, interest taking / payment is haram. Whereas the profitsharing system consists of: the determination of the profit sharing reached during the arrangement on the basis of profit/loss, the percentage of the profit-sharing ratio on the basis of the amount of profit obtained, the profit sharing depends on the outcome of the project. If the initiative does not gain a benefit or incur a loss, the risk is shared by all sides and the amount of profit increased by the increase in profit received is halal. 


\subsection{Bank Financial Statements}

According to Hanafi [9] said that, "The company's financial statements aim to summarize the activities and results of these activities for a certain period of time. Financial reports are important because they provide input (information) that can be used for decision making. Many parties have an interest in financial reports, starting from investors or potential investors, funders or potential funders, up to the management of the company itself."

In general, the objectives of making bank financial statements according to Kasmir [6] are as follows: provide financial information about the amount of assets, liabilities and bank capital at a certain time, provide financial information about total liabilities and types of liabilities both short term (current ) and longterm, provides financial information about the amount of capital and types of bank capital at a certain time, provides information about business results that are reflected in the amount of income earned and the sources of income of the bank, provides financial information about the amount of costs incurred, issues the types of costs incurred within a certain period, providing information about changes in assets, liabilities and capital of a bank, providing information about the performance of bank management in a given period from the results of the financial statements presented.

Financial statement analysis is very important for investors and companies, because they can find out the level of profit in the company.

Hanafi and Halim [9] said that, "Analysis of a company's financial statements is basically because you want to know the level of profitability (profit) and the level of risk or the health level of a company".

\subsection{Framework}

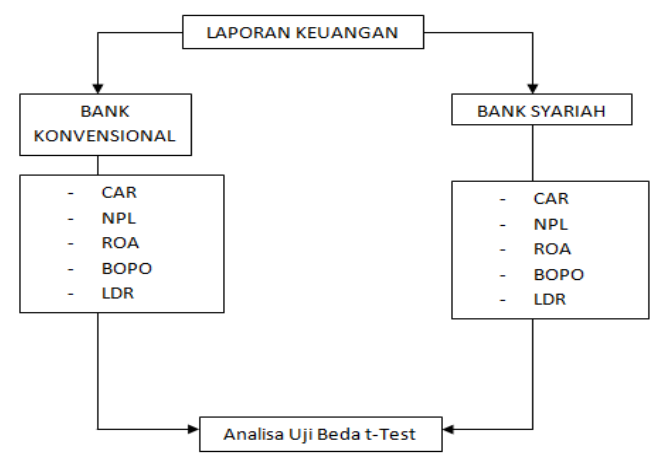

Figure 1. Framework
It can be seen in Figure 1 that the researcher compares financial performance using the bedat-test analysis.

\subsection{Development of Hypothesis}

\subsubsection{Difference of CAR (Capital Adequacy Ratio) Between Conventional Banks and Sharia Banks}

CAR is a capital adequacy ratio that works to address the possibility of failure that a bank can face. The higher the worth of the Vehicle, the greater the capacity of the bank to contend with the cost of any volatile credit or profitable assets. If the CAR is significant, the bank will be able to fund operating operations and make a comparatively significant contribution to profitability. This is in line with the study carried out by Vivin and Wahono [10], which indicates that there is a substantial gap between traditional banks and Sharia banks in terms of capital adequacy ratios as calculated by Vehicle.

The following argument can be made on the basis of the previously mentioned principle and earlier studies. $\mathrm{H}_{1}$ : There is a difference between the CAR (Capital Adequacy Ratio) of Conventional Banks and Sharia Banks.

\subsubsection{Difference of NPL (Non-Performing Loan) Between Conventional Banks and Sharia Banks}

NPL or non-performing loans are one of the main metrics for evaluating the performance of a bank's function. One of the duties of a bank is to serve as an intermediary entity or as a liaison between parties with an abundance of funds and others in need of funds. This is according to research conducted by [11], which indicates that conventional banks have better performances compared to Sharia banks in terms of earning asset quality ratio as measured by NPL.

The following argument can be made on the basis of the aforementioned principle and previous study. $\mathrm{H}_{2}$ : There is a difference in NPL (Non-Performing Loan) between Conventional Banks and Sharia Banks.

\subsubsection{Difference of ROA (Return on Asset) Between Conventional Banks and Sharia Banks}

ROA is a profitability ratio that calculates the capacity of an organization to produce income from the assets used. According to research conducted by Vivin and Wahono [10], there is a substantial gap between traditional banks and Sharia banks in terms of 
profitability ratios as calculated by ROA. Based on the opinion of Thayib et al. [11], it is clear that there is a substantial differential between traditional banks and Sharia banks in terms of profitability ratios as calculated by ROA. On the basis of the aforementioned theory and earlier studies, the following inference can be made. $\mathrm{H}_{3}$ : There is a difference in ROA (Return On Asset) between Conventional Banks and Sharia Banks.

\subsubsection{Difference of BOPO (Operating Costs of Operating Income)}

The BOPO ratio is the ratio for calculating the level of productivity and the capacity of the bank to work. This percentage calculates the sum of the rational expense and net interest of the bank. Debt and other operating expenses are included in operating costs. Furthermore, operating income ecompasses interest income and other operating profits. This is according to research conducted by Vivin and Wahono [10], which indicates that there is a substantial gap between Sharia banks and traditional banks in terms of corporate risk, as calculated by BOPO (Operational Cost of Operating Income). The following argument can be made on the basis of the aforementioned principle and previous study. H4: There is a disparity between Traditional Banks and Sharia Banks in BOPO (Operational Cost of Operating Income).

\subsubsection{Difference of LDR (Loan to Deposit Ratio) Between Conventional Banks and Sharia Banks}

LDR is the ratio of the overall amount of credit issued by the bank and the amount of credit earned by the bank. This ratio is used to consider the capacity of the bank to recover commitments to consumers who spend their funds with loans provided to their debtors. According to research conducted by Vivin and Wahono [10], there is a substantial discrepancy between Sharia Banks and Traditional Banks in terms of liquidity ratios as calculated by LDR. Based on the opinion of Wahyuni and Efriza [12], it shows that there is a significant difference in performance seen from the liquidity ratio as measured by LDR between Conventional Banks and Sharia Banks. Based on the opinion of Thayib et al. [11], it shows that there is a significant difference, that Sharia banks have better performance than conventional banks in terms of liquidity ratios as measured by LDR.

The following statement can be made on the basis of the identified principle and earlier studies. H5:
There is a difference in LDR (Loan to Deposit Ratio) between Conventional Banks and Sharia Banks.

\section{RESEARCH METHOD}

\subsection{Data and Sample}

This research utilizes secondary data which were compiled from regular banking and sharia banking companies mentioned within Indonesian Stock Exchange of 2014-2018. The sample used were 8 companies, in conventional banking 4 companies including state-owned enterprises that present the financial statements and ratios required in this study for five consecutive years, namely from 2014-2018 and in Islamic banking 4 companies with high assets and present financial reports and the ratios required in this study for five consecutive years, namely from 2014-2018. The total population in this study amounted to 40. The sampling technique was purposive sampling. Bank Rakyat Indonesia (BRI), Bank Negara Indonesia (BNI), Bank Tabungan Negara (BTN) and Bank Mandiri are also considered to follow the above conditions to be sampled as traditional banks. While the sample of Sharia Banks is Bank Muamalat Indonesia, Bank Mandiri Syariah, BRI Syariah, and BNI Syariah.

\subsection{Operational Definition of Variables}

In this study it was done using a comparison of financial performance. The variables used were financial ratios, among others:

a. Capital ratio, the ratio used in this equation is the CAR, which is the ratio of the sum of capital to the total assets weighted by the ratio (RWA) that is formulated [6]:

$\mathrm{CAR}=\frac{\text { Bank Capital }}{\text { Total ATMR }} \times 100 \%$

b. Earning Asset Quality Ratio, Calculation of earning asset quality (KAP) is measured using Non-Performing Loan (NPL), which is the ratio of earning assets classified to total earning assets. Earning assets ratio classified to total earning assets is calculated using the following formula [6].

$$
\mathrm{NPL}=\frac{\text { Total Non-Performing Loans }}{\text { Total of all credits }} \times 100 \%
$$

c. Analysis of bank profitability ratios is a tool for determining or estimating the success of a business and achieved profitability gained by the bank involved. The profitability ratio used 
in this analysis is (ROA). It can be formulated as follows [6].

$\mathrm{ROA}=\frac{\text { Profit before tax }}{\text { Total assets }} \times 100 \%$

d. Company risk, company risk can be measured by looking for the formulated Operating Costs (BOPO) [6].

$$
\text { BOPO }=\frac{\text { Operating costs }}{\text { Operating income }} \times 100 \%
$$

e. Liquidity Ratio

The liquidity ratio is a ratio that defines the willingness of the company to satisfy its shortterm obligations. The liquidity ratio represented by the Loan to Debt Ratio (LDR) [6], using the following formula.:

LDR $=\frac{\text { Credit given }}{\text { Third-party funds }} \times 100 \%$

\subsection{Data Analysis}

In this study it was done using different test. While the tool used to evaluate the data in this analysis was version 25 of SPSS.

\section{RESULTS AND DISCUSSION}

\subsection{Descriptive Analysis}

Table 1. Descriptive Statistics Test Results of Conventional Banks

\begin{tabular}{|c|c|c|c|c|c|}
\hline \multicolumn{6}{|c|}{ Descriptive Statistics } \\
\hline & $\mathbf{N}$ & $\begin{array}{c}\text { Minimu } \\
\text { m }\end{array}$ & $\begin{array}{c}\text { Maximu } \\
\text { m }\end{array}$ & Mean & $\begin{array}{c}\text { Std. } \\
\text { Deviati } \\
\text { on }\end{array}$ \\
\hline CAR & 20 & 14.64 & 22.96 & $\begin{array}{r}19.313 \\
5\end{array}$ & 2.21847 \\
\hline BOPO & 20 & 64.98 & 88.97 & $\begin{array}{r}73.873 \\
0\end{array}$ & 7.46371 \\
\hline ROA & 20 & 1.14 & 4.73 & 2.8275 & .99985 \\
\hline NPL & 20 & 1.66 & 4.01 & 2.5890 & .70400 \\
\hline LDR & 20 & 81.68 & 108.86 & $\begin{array}{r}91.933 \\
0\end{array}$ & 8.54568 \\
\hline $\begin{array}{l}\text { Valid } \\
\mathrm{N} \\
\text { (listwi } \\
\text { se) }\end{array}$ & 20 & & & & \\
\hline
\end{tabular}

Based on the table above, it can be explained as follows: Conventional bank's CAR ratio value has a minimum value of $14.64 \%$ (Bank Mandiri in 2014), while conventional bank's CAR ratio is a maximum of
$22.96 \%$ (BRI Bank in 2017). The average (mean) CAR ratio of conventional banks is $19.3135 \%$ with a standard deviation of $2.21847 \%$. The BOPO ratio value of conventional banks has a minimum value of $64.98 \%$ (Bank Mandiri in 2014), while the maximum BOPO ratio of conventional banks is $88.97 \%$ (Bank BTN in 2014). The average (mean) BOPO ratio of conventional banks is $73.8730 \%$ with a standard deviation of $7.46371 \%$. The ROA ratio of conventional banks has a minimum value of $1.14 \%$ (Bank BTN in 2014), while the ROA ratio of conventional banks is a maximum of $4.73 \%$ (BRI Bank in 2014). The average value (mean) of conventional bank ROA ratio is $2.8275 \%$ with a standard deviation of $0.99985 \%$. The value of the NPL ratio of conventional banks has a minimum value of $1.66 \%$ (Bank Mandiri in 2014), while the value of the NPL ratio of conventional banks is a maximum of $4.01 \%$ (Bank BTN in 2014). The average (mean) NPL ratio of conventional banks is $2.5890 \%$ with a standard deviation of $0.70400 \%$. The value of the LDR Ratio of conventional banks has a minimum value of $81.68 \%$ (BRI Bank in 2014), while the maximum value of the LDR Ratio of conventional banks is $108.86 \%$ (Bank BTN in 2014). The average (mean) LDR ratio of conventional banks is $91.9330 \%$ with a standard deviation of $8.54568 \%$.

Table 2. Descriptive Statistics Test Results of Shariah Banks

\begin{tabular}{|c|c|c|c|c|c|}
\hline \multicolumn{6}{|c|}{ Descriptive Statistics } \\
\hline & $\mathbf{N}$ & $\begin{array}{l}\text { Mini } \\
\text { mum }\end{array}$ & $\begin{array}{l}\text { Maxim } \\
\text { um }\end{array}$ & Mean & $\begin{array}{c}\text { Std. } \\
\text { Deviation }\end{array}$ \\
\hline CAR & 20 & 12.00 & 29.72 & 16.0540 & 4.21206 \\
\hline BOPO & 20 & 85.37 & 100.60 & 93.8920 & 4.41181 \\
\hline ROA & 20 & -.04 & 1.44 & .6485 & .50893 \\
\hline NPL & 20 & 1.86 & 7.11 & 4.2510 & 1.48032 \\
\hline LDR & 20 & 71.87 & 95.13 & 83.0475 & 6.78647 \\
\hline $\begin{array}{l}\text { Valid } \\
\mathrm{N} \\
\text { (listwi } \\
\text { se) }\end{array}$ & 20 & & & & \\
\hline
\end{tabular}

(Source: Data processing from SPSS 25, 2019)

On the basis of the above table, it can be clarified that the value of the CAR ratio of Shariah banks has a minimum value of $12 \%$ (Bank Muamalat in 2015), while the maximum Sharia bank CAR ratio is $29.72 \%$ (Bank BRI Syariah in 2018). The average (mean) CAR ratio of Sharia banks is $16.0540 \%$ with a standard deviation of $4.21206 \%$. The BOPO Ratio value of Sharia banks has a minimum value of $85.37 \%$ (Bank BNI Syariah in 2018), while the maximum value of the BOPO Ratio of Sharia banks is $100.60 \%$ (Bank Mandiri Syariah in 2014). The average value of the 
BOPO ratio of Sharia banks is $93,8920 \%$ with a standard deviation of $4,41181 \%$. The value of the ROA ratio of Sharia banks shall have a minimum value of-0.04 per cent. (Bank Mandiri Syariah in 2014), while the maximum value of the ROA of Sharia banks is $1.44 \%$ (Bank BNI Syariah in 2016). The average ROA value of Sharia banks is $0.6485 \%$ with a standard deviation of $0.50893 \%$. The value of the NPL ratio of Sharia banks has a minimum value of $1.86 \%$ (Bank BNI Syariah in 2014), while the maximum value of the NPL ratio of Sharia banks is $7.11 \%$ (Bank Muamalat in 2015). The average (mean) value of the NPL ratio of Sharia banks is $4.2510 \%$ with a standard deviation of $1.48032 \%$. The value of the LDR Ratio of Sharia banks has a minimum value of $71.87 \%$ (Bank BRI Syariah in 2017), while the maximum value of the LDR of Sharia banks is $95.13 \%$ (Bank Muamalat in 2016). The average (mean) LDR ratio of Sharia banks is $83.0475 \%$ with a standard deviation of $6.78647 \%$.

\subsection{T-test}

This t-test indicates that there is a substantial difference or no significant difference between traditional banks and Shariah banks. If the significant value in the column of the Levene Test for Equal Variance is greater $(>)$ than 0.05 , where $\mathrm{H} 0$ is accepted and $\mathrm{H} 1$ is refused, so both banks have the same variant, if the significant value is less than $(<)$ in the t-test column for Equality of Means, where $0.05 \mathrm{H0}$ is refused and $\mathrm{H} 1$ is accepted, there is a significant difference. Hypothesis testing in the different test is presented in the following table:

Table 3. Statistical Test Results of the Independent Sample t-Test

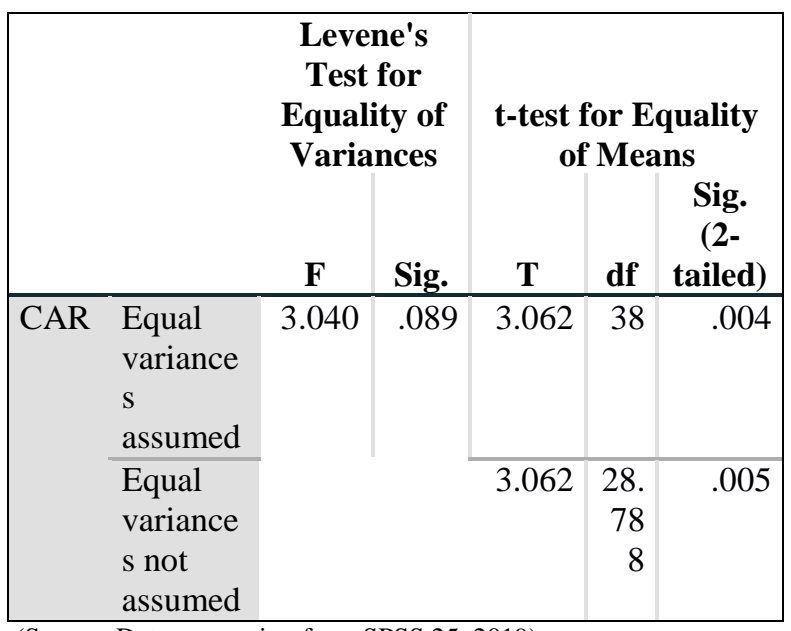

(Source: Data processing from SPSS 25, 2019)
Based on the findings of the study, the significance value $(0.004$ and 0.005$)<0.05$ can be found in the $t-$ test column for Equivalent Means, then $\mathrm{H} 0$ is approved and $\mathrm{H} 1$ is refused, which means that there is no substantial difference between the CAR Ratio of Traditional Banks and the CAR Ratio of Sharia Banks.

Table 4. Statistical Test Results of the Independent Sample t-Test

\begin{tabular}{|c|c|c|c|c|c|c|}
\hline & \multicolumn{2}{|c|}{$\begin{array}{c}\text { Levene's } \\
\text { Test for } \\
\text { Equality of } \\
\text { Variances }\end{array}$} & \multicolumn{3}{|c|}{$\begin{array}{c}\text { t-test for Equality of } \\
\text { Means }\end{array}$} \\
\hline & & $\mathbf{F}$ & Sig. & $\mathbf{T}$ & Df & $\begin{array}{c}\text { Sig. } \\
(2- \\
\text { tailed) }\end{array}$ \\
\hline \multirow[t]{2}{*}{ BOPO } & $\begin{array}{l}\text { Equal } \\
\text { variances } \\
\text { assumed }\end{array}$ & 7.638 & .009 & -10.326 & 38 & .000 \\
\hline & $\begin{array}{l}\text { Equal } \\
\text { variances } \\
\text { not } \\
\text { assumed }\end{array}$ & & & -10.326 & $\begin{array}{r}30.83 \\
3\end{array}$ & .000 \\
\hline
\end{tabular}

Based on the findings of the study, the value $(0.000)<0.05$ is seen in the t-test column for Equality of Means, then $\mathrm{HO}$ is refused and $\mathrm{H} 1$ is accepted, which means that there is a substantial disparity between the BOPO Ratio of Traditional Banks and the BOPO Ratio of Sharia Banks.

Table 5. Statistical Test Results of the Independent Sample t-Test

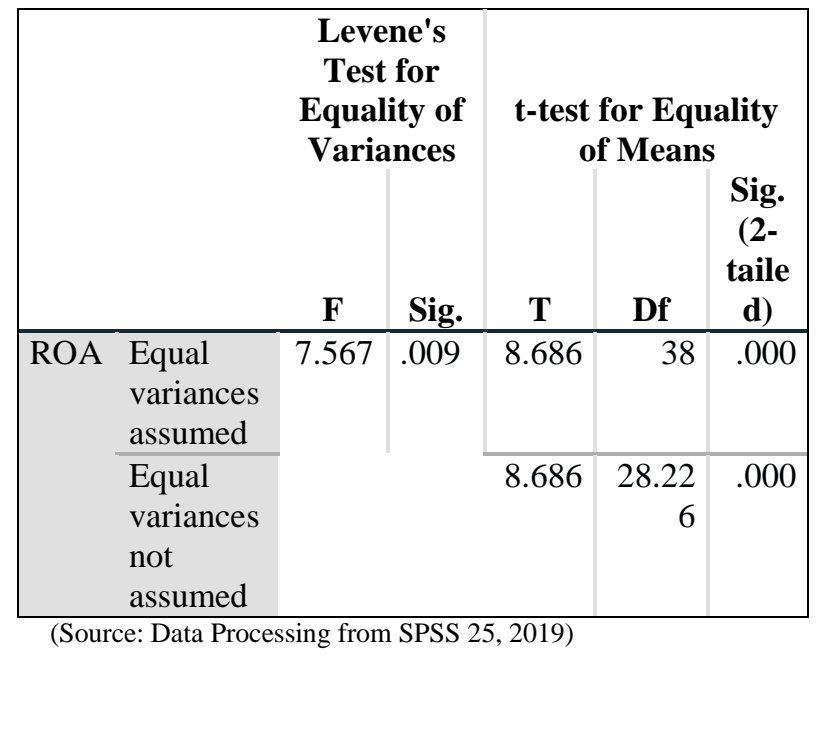


Based on the outcome of the study, the value $(0.000)<0.05$ is seen in the t-test column for Equality of Means, then H0 is refused and H1 is accepted, which means that there is a substantial disparity between the ROA ratio of Traditional Banks and the ROA ratio of Shariah Banks.

Table 6 Statistical Test Results of the Independent Sample t-Test

\begin{tabular}{|c|c|c|c|c|c|}
\hline & \multicolumn{2}{|c|}{$\begin{array}{c}\text { Levene's } \\
\text { Test for } \\
\text { Equality of } \\
\text { Variances }\end{array}$} & \multicolumn{3}{|c|}{$\begin{array}{c}\text { t-test for Equality of } \\
\text { Means }\end{array}$} \\
\hline & $\mathbf{F}$ & Sig. & $\mathbf{T}$ & df & $\begin{array}{l}\text { Sig. } \\
(2- \\
\text { taile } \\
\text { d) }\end{array}$ \\
\hline \begin{tabular}{|ll}
$\mathrm{N}$ & Equal \\
$\mathrm{P}$ & variances \\
$\mathrm{L}$ & assumed
\end{tabular} & 8.907 & .005 & -4.534 & 38 & .000 \\
\hline $\begin{array}{l}\text { Equal } \\
\text { variances } \\
\text { not } \\
\text { assumed }\end{array}$ & & & -4.534 & 27.176 & .000 \\
\hline
\end{tabular}

(Source: Data processing from SPSS 25, 2019)

Based on the findings of the study, the value $(0.000)<0.05$ is seen in the t-test column for Equality of Means, then $\mathrm{H} 0$ is denied and $\mathrm{H} 1$ is accepted, which means that there is a substantial discrepancy between the NPL Ratio of Traditional Banks and the NPL Ratio of Sharia Banks.

Table 7 Statistical Test Results of the Independent Sample t-Test

\begin{tabular}{|c|c|c|c|c|c|c|}
\hline & \multicolumn{2}{|c|}{$\begin{array}{c}\text { Levene's } \\
\text { Test for } \\
\text { Equality of } \\
\text { Variances }\end{array}$} & \multicolumn{3}{|c|}{$\begin{array}{c}\text { t-test for Equality } \\
\text { of Means }\end{array}$} \\
\hline & & $\mathbf{F}$ & Sig. & $\mathbf{t}$ & df & $\begin{array}{l}\text { Sig. } \\
(2- \\
\text { tail } \\
\text { ed })\end{array}$ \\
\hline $\begin{array}{l}\mathrm{LD} \\
\mathrm{R}\end{array}$ & $\begin{array}{l}\text { Equal } \\
\text { variance } \\
\mathrm{s} \\
\text { assumed }\end{array}$ & \multirow[t]{2}{*}{1.558} & \multirow[t]{2}{*}{.220} & 3.641 & 38 & .001 \\
\hline & $\begin{array}{l}\text { Equal } \\
\text { variance } \\
\text { s not } \\
\text { assumed }\end{array}$ & & & 3.641 & $\begin{array}{r}36.14 \\
6\end{array}$ & .001 \\
\hline
\end{tabular}

(Source: Data Processing from SPSS 25, 2019)

Based on the outcome of the analysis, the significance value $(0.001)<0.05$ is rejected and $\mathrm{H} 0$ is approved in the t-test column for Equality of Means, which means that there is a significant disparity between the LDR Ratio of Traditional Banks and the LDR Ratio of Sharia Banks.

\subsection{Discussion}

a. The results showed that CAR for Conventional Banks and CAR for Sharia Banks have a significant difference. This difference is caused by the level of capital in conventional banks which is different from Sharia banks. The findings of this analysis are backed by research conducted by [10] which found that there was no substantial difference between the CAR of conventional banks and Sharia banks, as opposed to research conducted by Thayib et al. [11] which found that traditional bank CAR and Sharia bank CAR had significant variations. Where the capital adequacy ratio is higher, the bank's performance level will also increase. With the relatively large amount of capital in a particular bank, it will foster public confidence in saving or depositing funds at the bank concerned and if the capital is managed appropriately, it will be able to boost its profitability.

b. The results showed that BOPO for Conventional Banks and BOPO for Sharia Banks have significant differences. This disparity is attributed to variations in the size of the bank's operational expenses and operating profits. The findings of this study contrast with the research of [10] and the research of [12] which showed that there was no difference in BOPO between traditional banks and Sharia banks. Where the less the BOPO, the more effective the bank is in carrying out its commercial operations, so the operational expenses to be incurred are lower than the operating revenue, meaning that the bank's operating activities produce revenues, which is able to increase bank capital and minimize the level of risk and provide confidence to investors who will invest its shares in the company.

c. The results of this study indicate that the ROA of conventional banks and ROA of Sharia banks have a significant difference. This difference is attributed to a higher rate of return net profit on traditional banks than on Sharia banks. The findings of this study are confirmed by research conducted by Purnamasari and Ariyanto [13], which showed that there are variations. ROA of conventional banks and Sharia banks and backwards with analysis by Thayib et al.[11] found that there was no substantial gap between ROA of conventional banks and Sharia banks. The higher the bank's ROA, the higher the bank's profit. In addition, the role of the bank in terms of asset utilization is also improving. 
This convinces investors to invest in a business when it will produce large returns for investors.

d. The NPL between traditional banks and Sharia Banks show a significant difference. This difference is due to the lower non-performing loans of conventional banks than Sharia banks. The findings of this analysis are confirmed by studies performed by Thayib et al. [11] which finds that there are substantial differences. NPL of conventional banks with Sharia banks and contrary to research by [12]. Where the higher the NPL value, the worse the quality of productive assets with the quality of problem assets. Where non-performing loans are groups of debtors who are categorized as substandard debtors, doubtful and stuck.

e. It is indicated that the LDR of conventional banks and Sharia banks have a significant difference. This difference is attributed to a higher overall credit of traditional banks than Sharia banks. The findings of this study are backed by research [10] and research [11] which showed that there is a substantial gap in the LDR between traditional banks and Sharia banks. Where the higher the LDR shows an indication of the lower liquidity of a bank, this is linked to the higher volume of funds intended to finance lending and, if there is a reduction in the LDR beyond the regular BI regulations, therefore a declining of willingness for banks to pay their short-term obligations is present.

\section{CONCLUSIONS}

CAR for Conventional Banks and CAR for Sharia Banks have significant differences. Conventional banks have a CAR that is greater than Sharia banks. BOPO for Conventional Banks and BOPO for Sharia Banks have a significant difference. Conventional banks have BOPO that is smaller than Sharia banks. ROA of Conventional Banks and ROA of Sharia Banks have a significant difference. Conventional banks have greater ROA than Sharia banks. There is a significant difference between Conventional Bank NPL and Sharia Bank NPL. Sharia banks have higher NPLs than conventional banks. LDR for Conventional Banks and LDR for Sharia Banks have a significant difference. Conventional banks have a higher LDR than Sharia banks. From the above conclusion, it can be interpreted that conventional banks have better performance at the ratio of CAR, OEOI, ROA, NPL and in Sharia banks the better their performance is at the LDR ratio.

In this study, there are still limitations in the use of the data analysis which is still not maximal. Therefore, for improvement, the researcher is expected to be able to develop with better findings or innovations.

For researchers who wish to conduct similar research, it is advisable to use more variables and a larger number of samples and a longer observation year, namely by not comparing between BUMN Conventional Banks and Sharia Banks which have the highest assets, but also with other banks. such as Bank BCA, Bank Danamon, Bank Bukopin, Bank Mega, and Bank Syariah which not only have high assets, so they are expected to obtain optimal results and be able to explain the financial performance comparison between conventional banks and Sharia banks as a whole, as well as get comprehensive results or wider and more complete.

\section{AUTHORS' CONTRIBUTIONS}

Provide an understanding of the gaps in performance between conventional banks and Sharia banks.

\section{ACKNOWLEDGMENTS}

I would like to thank various people for their guidance, enthusiastic encouragement and useful critiques for this project. My grateful thanks are also extended to Universitas Merdeka Madiun for the support throughout this research.

\section{REFERENCES}

[1] Muhammad, 2005, Manajemen Bank Syariah, UPP AMP YKPN, Yogyakarta

[2] Abustan, 2009

[3] Dendawijaya, Lukman, 2009, Manajemen Perbankan, Jakarta: Graha Indonesia

[4] www.Bi.go.id

[5] Blooket Perbankan Indonesia, 2011, Jakarta: Bank Indonesia

[6] Kasmir, 2003, Manajemen Perbankan, Jakarta: PT.Raja Grafindo Persada

[7] Antonio, 2005, Bank Syariah dari Teori ke Praktik, (UPP) AMP YKPN Yogyakarta

[8] Macmud dan Rukmana, 2010, Bank Syariah, Teori, Kebijakan, dan Studi Empiris di Indonesia. Cikaras, Jakarta : Erlangga

[9] Hanafi, Halim, Analisis Laporn Keuangan, Cetakan ke-4, UPP STIM YKPN 
[10] Vivin, Wahono, 2016, Analisis Perbandingan Kinerja Keuangan Bank Umum Syariah dengan Bank Umum Konvensional Indonesia, Jurnal Fakultas Ekonomi Unisma

[11] Thayib et al., 2017, Analisis Perbandingan Kinerja Keuangan Bank Syariah dan Bank Konvensional, Jurnal Fakultas Ekonomi dan Bisnis, Jurusan Manajemen Universitas Sam Ratulangi Manado, Vol.5 N0.2 Juni 2017

[12]Wahyuni, Efriza, 2017, Analisis Perbandingan Kinerja Keuangan Bank Syariah dengan Bank Konvensional di Indonesia, International Journal of Social Science and Business, Vol. 1 (2) pp

[13]Purnamasari, Ariyanto, 2016, Analisis Perbandingan Kinerja Keuangan Bank Konvensional dan Bank Syariah Periode 20101024, Jurnal Fakultas Ekonomi dan Bisnis Universitas Udayana (Unud), Bali, Indonesia, Vol.15.1. April 2016. 